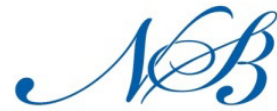

Notulae Scientia Biologicae

\title{
Soil Seed Bank Dynamics of a Riparian Forest and its Adjacent Upland Vegetation
}

\author{
Omowumi Omotoyosi OLALOYE*, Samson Olajide OKE
}

\author{
Obafemi Awolowo University, Faculty of Science, Department of Botany, Ile-Ife, Nigeria: \\ olaloyeomowumi84@yahoo.com*(correspondingauthor);soke@oauife.edu.ng
}

\begin{abstract}
The present study was conducted to determine the densities and soil seed bank composition of a riparian forest and its adjacent upland vegetation for a better understanding the potentials of the soil seed banks in facilitating succession towards a more natural forest of native tree species. Three contiguous $20 \mathrm{~m}$ x $20 \mathrm{~m}$ plots were systematically established on both riparian forest and upland vegetation. Species enumeration, identification and distribution into families of the standing vegetation were carried out. Furthermore, five replicates soil samples were collected at two different depths $(0-15 \mathrm{~cm}, 15-30$.The seedling emergence test was carried out for six months in the greenhouse to determine the species composition and the density of the seed in both vegetation types. The results of the seedling emergence revealed that more seeds were deposited at the upper depth $(0-15 \mathrm{~cm})$ than the lower depth $15-30 \mathrm{~cm}$ in the two vegetation types in both dry and rainy season. There was low similarity in species composition between the standing vegetation and soil seed bank in each of the two vegetation types. Herbaceous species recorded the highest number of seedlings as compared to the other habit. The low similarity between seed bank and standing vegetation of the riparian forest and the adjacent upland vegetation suggested that soil seed bank was insignificant in their restoration.
\end{abstract}

Keywords: depth, re-vegetation, riparian forest, soil seed bank, species diversity

\section{Introduction}

Riparian forests are one of the biospheres' most complex ecological systems but also are important for maintaining the vitality of landscape and its rivers (Naiman and Decamps, $1990 ; 1997)$. Vegetation in riparian areas is generally characterized by its high species richness and has unique characters making it different from the upland vegetation (Naiman et al., 1993). Despite their limited area extent, riparian areas promote many ecosystem functions vital to the health and productivity of forested watersheds (Gregory et al., 1991). The riparian areas regulate the flow of water, sediments, and nutrients across system boundaries; they also contribute with organic material to the aquatic system, increase bank stability, reduce erosion, and provide key wildlife habitat (Gregory et al., 1991). Moreover, because of their functional importance, riparian areas play important roles in reducing many of the negative impacts of land use on aquatic systems as well as protecting species diversity, providing potential dispersal corridors for wildlife, and reducing flood waters (Ilhardt et al., 2000).

On restored sites, target species can establish in the plant community through dispersal from source plant communities, or through germination from viable seeds in the soil seed bank (Bakker and Berendse, 1999). This soil seed bank can also contain seeds of non- target species, which may rather hamper the establishment of target species by interspecific competition (Bossuyt et al., 2002). In order to understand the soil seed bank dynamics in degraded forests, which include gains through seed rain, losses due to seed predation, seed death and transfer into the active seed bank to germinate and form a seedling bank, is necessary before deciding whether intervention is needed to assist the natural regeneration process (Augusto Uasuf et al., 2009).

Nowadays there is an increasing demand for reliable information on seed banks, both for scientific purposes and as a decision tool in habitat and landscape management, particularly restoration projects (Holzel and Otte, 2004). Despite the importance of the soil seed bank as a determinant of the flora in many systems, little research has been conducted on the seed banks of riparian forests especially in southwestern Nigeria. The present study attempts to assess the soil seed bank composition and its role in the restoration of degraded riparian and upland vegetation. The main objectives were: to determine the species composition and density of the seed bank in both vegetation types; to compare the seasonal variation of the soil seed bank of the standing vegetation in both the riparian and upland vegetations and to note the effect of depths on the soil seed bank in the two vegetation types.

\section{Materials and Methods}

\section{The studied areas}

The study was carried out within Obafemi Awolowo University (OAU) community in Ile-Ife $\left(7^{\circ} 31^{\prime} \mathrm{N}\right.$ and $7^{\circ} 32^{\prime} \mathrm{N}$ latitude, $4^{\circ} 31^{\prime} \mathrm{E}$ and $4^{0} 32^{\prime} \mathrm{E}$ longitude), Osun state, Nigeria. IleIfe is in the lowland forest zone according to Keay (1959), semi deciduous moist forests Charter (1969). The area lies in the dry 
Table 1. Mean density of woody species (per hectare) in the two vegetation types

\begin{tabular}{|c|c|c|c|c|}
\hline No.of entry & Species names & Family & Riparian forest & Upland vegetation \\
\hline 1. & Albizia adianthifolia & Mimosoideae & 50 & 33 \\
\hline 2. & Albizia lebbeck & Mimosoideae & - & 8 \\
\hline 3. & Albizia zygia & Mimosoideae & 117 & 408 \\
\hline 4. & Alchornea cordifolia & Euphorbiaceae & 375 & 133 \\
\hline 5. & Alchornea laxiflora & Euphorbiaceae & - & 375 \\
\hline 6. & Allophyllus africanus & Sapindaceae & 8 & - \\
\hline 7. & Alstonia boonei & Apocynaceae & 17 & - \\
\hline 8. & Anchomanis difformis & Arecaceae & - & 50 \\
\hline 9. & Anthocleista djalonensis & Loganiaceae & 108 & - \\
\hline 10. & Anthocleista vogelii & Loganiaceae & - & 8 \\
\hline 11. & Antiaris africana & Moraceae & 17 & 50 \\
\hline 12. & Azadirachta indica & Meliaceae & 50 & 258 \\
\hline 13. & Baphia nitida & Papilioniaceae & 17 & 8 \\
\hline 14. & Blighia sapida & Sapindaceae & - & 16 \\
\hline 15. & Bombax buonopozense & Bombacaceae & 33 & 8 \\
\hline 16. & Bridelia ferruginea & Euphorbiaceae & 8 & 17 \\
\hline 17. & Canthium vulgare & Rubiaceae & 50 & - \\
\hline 18. & Carpolobia lutea & Phytolacaceae & 33 & - \\
\hline 19. & Cassia siberiana & Cealsapinaceae & 25 & - \\
\hline 20. & Ceiba pentandra & Bombacaceae & 25 & - \\
\hline 21. & Celtis zenkeri & Ulmaceae & 25 & - \\
\hline 22. & Cnestis ferrugiana & Connaraceae & 8 & 17 \\
\hline 23. & Deinbollia maxima & Sapindaceae & 8 & - \\
\hline 24. & Deinbollia pinnata & Sapindaceae & 17 & - \\
\hline 25. & Delonix regia & Cealsapinaceae & - & 150 \\
\hline 26. & Drypetes sp & Euphorbiaceae & 8 & - \\
\hline 27. & Ficus capensis & Moraceae & 50 & - \\
\hline 28. & Ficus sp & Moraceae & - & 17 \\
\hline 29. & Funtumia elastica & Apocynaceae & 33 & - \\
\hline 30. & Glyphaea brevis & Tiliaceae & 17 & - \\
\hline 31. & Harungana madagascariensis & Apocynaceae & - & 8 \\
\hline 32. & Hedranthera bacteri & Apocynaceae & - & 5 \\
\hline 33. & Hipocratea sp & Celastraceae & 7 & \\
\hline 34. & Holarrbena floribunda & Apocynaceae & 475 & 92 \\
\hline 35. & Icacina tricantha & Icacinacaceae & - & 250 \\
\hline 36. & Lannea welwitschii & Anacardiaceae & 8 & - \\
\hline 37. & Leea guinensis & Leeaceae & 8 & - \\
\hline 38. & Mallotus oppositifolius & Apocynaceae & - & 83 \\
\hline 39. & Margaritaria discoidea & Euphorbiaceae & 50 & 225 \\
\hline 40. & Markhamia tomentosa & Bignonaceae & 8 & - \\
\hline 41. & Microdesmis puberula & Pandaceae & 8 & - \\
\hline 42. & Monodora tenuifolia & Annonaceae & - & 8 \\
\hline 43. & Morinda lucida & Rubiaceae & 28 & 8 \\
\hline 44. & Napoleona imperialis & Lecythidaceae & 8 & 33 \\
\hline 45. & Napoleonaea vogelli & Lecythidaceae & - & 33 \\
\hline 46. & Newbouldia laevis & Bignonaceae & 25 & 66 \\
\hline 47. & Ochna sp & Ochnaceae & - & 40 \\
\hline 48. & Piptadeniastrum africanum & Mimosaceae & 8 & - \\
\hline 49. & Psidium guajava & Myrtaceae & 17 & 8 \\
\hline 50. & Rauvolfia vomitora & Apocynaceae & 8 & 33 \\
\hline 51. & Rothmania longiflora & Apocynaceae & - & 8 \\
\hline 52. & Sphenocentrum jollyanum & Menispermaceae & - & 33 \\
\hline 53. & Spondias mombin & Anarcadiaceae & - & 50 \\
\hline 54. & Sterculia tragacantha & Sterculiaceae & - & 50 \\
\hline 55. & Terminalia superba & Combretaceae & 8 & - \\
\hline 56. & Tetrapleura tetraptera & Mimosaceae & - & 17 \\
\hline 57. & Trema orientalis & Ulmaceae & - & 8 \\
\hline 58. & Trichilia sp & Meliaceae & - & 8 \\
\hline 59. & Vitex doniana & Verbanaceae & - & 8 \\
\hline 60. & Vitex grandifolia & Verbanaceae & 17 & - \\
\hline 61. & Voacanga africana & Apocynaceae & - & 8 \\
\hline \multirow[t]{2}{*}{62.} & Xylopia paviflora & Annonaceae & - & 8 \\
\hline & TOTAL & & 1749 & 2235 \\
\hline
\end{tabular}

deciduous forest zone (Onochei, 1979). According to White (1983) the vegetation was described as Guineo-Congolian drier forest type.

The mean annual rainfall is about $1400 \mathrm{~mm}$ and the mean maximum temperature of $33^{\circ} \mathrm{C}$ is recorded between February and March while the mean minimum temperature of $27^{\circ} \mathrm{C}$ is recorded between July and September (Oke and Isichei, 1997). Two distinct vegetation types (riparian forest and upland vegetation) were selected in OAU community base on their vegetation physiognomy. 
Table 2. Climber species in the two studied standing vegetation system

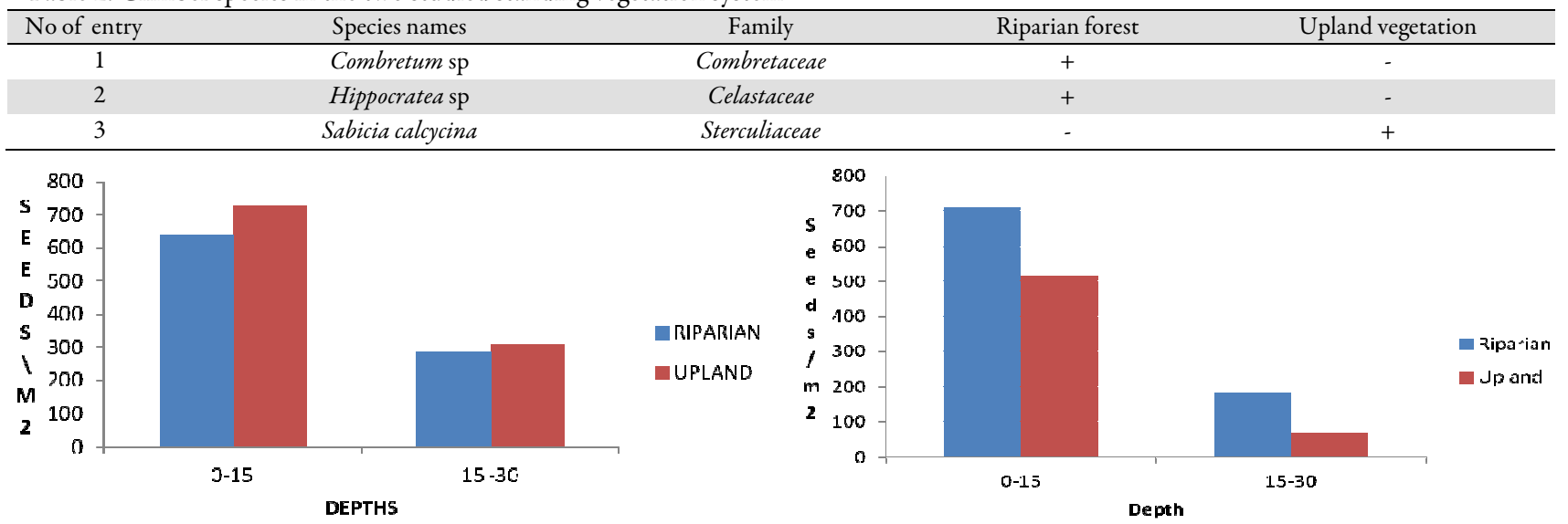

Fig. 1. Seed density at different depths in the two vegetation types in dry season

\section{Soilsamples and the species identification}

Three sample plots $20 \mathrm{~m}$ x $20 \mathrm{~m}$ each were selected within each vegetation type. All the woody species (trees and shrubs) greater than or about one meter in height on the selected plots were identified to species level and completely enumerated. The identification followed the Flora of West Africa (Hutchinson and Dalziel, 1954-1972). Unidentified plants were collected dried and pressed for identification by a taxonomist in IFE Herbarium. In each of the six plots, five replicate soil samples were randomly collected at two depths $(0-15 \mathrm{~cm}, 15-30 \mathrm{~cm})$ using a soil auger. Soil samples were collected in March 2011 for dry season collection while the rainy season collection in June 2011. Sixty samples (60) were collected in each of the riparian and upland vegetation in each season making a total of 120 samples collected from both sites in the two seasons (rainy and dry season). The soil samples collected were spread in porous plates for seeds germination under nursery conditions in the greenhouse where they were watered daily and monitored for seedling emergence. As seedlings emerged, the seedlings in each plate were identified, counted and removed. The seedling emergence test was terminated at the end of six months for soil samples collected from each of the six plots in both dry and rainy seasons. The number of seedlings that emerged per $\mathrm{m}^{2}$ were counted using the method of Mayor and Pyott (1966).

\section{The statistical analyses}

Sorenson index of similarity (Sorensen, 1948) was used to compare the species composition between the extent vegetation and the soil seed bank. Two-way analysis of variance (ANOVA) was used to test for any significant difference in soil seed bank of the two vegetation types in different seasons and different depths

\section{Results}

\section{Species composition of the standing vegetation}

In the riparian forest thirty-eight woody species were encountered while forty woody species were encountered in the upland vegetation. A total of sixty-two woody species were observed in the two vegetation types (Table 1). Climber species observed in the two vegetation types include Combretum sp, Hippocrateasp and Sabicia calcycina (Table 2).

\section{Seedling emergence at $0-15 \mathrm{~cm}$ depth}

In the dry season, a total mean of 107 seedlings or 640
Fig. 2. Seed density at different depths in the two vegetation types in rainy season

seeds $/ \mathrm{m}^{2}$ emerged in the riparian forest at $0-15 \mathrm{~cm}$ depth (Table 3). Thirty-four species emerged in this site consisting of three woody species namely Alchornea cordifolia, Harungana madagascariensis and Trema orientalis.

In upland vegetation, a total mean of 121 seedlings or 728 seeds $/ \mathrm{m}^{2}$ emerged (Table 4). Forty-one species emerged in this site consisting of two woody species namely Grewia orientalis and Trema orientalis.

In the rainy season, 708 seeds $/ \mathrm{m}^{2}$ emerged in riparian forest at $0-15 \mathrm{~cm}$ depth (Table 3 ). Ten species emerged from this site comprising of two woody species which are Mallotus oppositifolius and Elaies guineensis. They constituted about $25.77 \%$ of the total seed bank density while others which were herbaceous made up $74.23 \%$ of the total seed bank. In upland vegetation, 516 seeds $/ \mathrm{m}^{2}$ emerged. Twenty species emerged in upland vegetation with only one woody species (Elaeis guineensis).

\section{Seedling emergence at $15-30 \mathrm{~cm}$ depth}

In the dry season, 286 seeds $/ \mathrm{m}^{2}$ emerged in the riparian forest (Table 3). Fifteen species emerged in which only one woody species Trema orientalis was identified. In upland vegetation, 310 seeds $/ \mathrm{m}^{2}$ emerged (Table 4). Nineteen species emerged from this site where Grewia orientalis was the only woody species present in the vegetation and it constituted $1.94 \%$ of the total seed bank density while the remaining herbaceous species made up $98.06 \%$ of the total seed bank.

In the rainy season, 182 seeds $/ \mathrm{m}^{2}$ emerged in the riparian forest, (Table 3 ). Four species emerged with only one woody species. The woody species (Mallotus oppositifolius) accounted for $3.30 \%$ of the seed bank while herbaceous species made up $88.30 \%$ of the seed bank density. A mean of 70 seeds $/ \mathrm{m}^{2}$ emerged in the upland vegetation (Table 4). All the five species that emerged from this site were herbs. The results show that there was a significant difference $(p<0.05)$ in the density of seedlings at the two different depths. Soil seed bank density was also significantly different in the two vegetation types ( $p$ $<0.05$ ) in rainy and dry season. A graphical representation showing seed density at different depths in the two vegetation types in rainy and dry season is presented below in Figs. 1 and 2. 
Table 3. Mean density $\left(\right.$ seeds $\left./ \mathrm{m}^{2}\right)$ and percentage contribution of each species in the seed bank of riparian forest in both dry and rainy season at $0-15 \mathrm{~cm}$ and $15-30 \mathrm{~cm}$

\begin{tabular}{|c|c|c|c|c|c|c|c|c|c|}
\hline \multirow[b]{2}{*}{$\mathrm{S} / \mathrm{N}$} & \multirow[b]{2}{*}{ Species } & \multicolumn{3}{|c|}{ Dry season $\left(\right.$ seeds $\left./ \mathrm{m}^{2}\right)$} & \multicolumn{5}{|c|}{ Rainy season $\left(\right.$ seed $\left./ \mathrm{m}^{2}\right)$} \\
\hline & & $0-15 \mathrm{~cm}$ & $\begin{array}{c}\% \text { seed } \\
\text { bank }\end{array}$ & $15-30 \mathrm{~cm}$ & $\%$ seed bank & $0-15 \mathrm{~cm}$ & $\begin{array}{c}\% \text { seed } \\
\text { bank }\end{array}$ & $15-30 \mathrm{~cm}$ & $\%$ seed bank \\
\hline 1 & Adenia sp. & 06 & 0.93 & - & - & - & - & - & - \\
\hline 2 & Ageratum conyzoides & 06 & 0.93 & 06 & 2.10 & - & - & - & - \\
\hline 3 & Alchornea cordifolia & 06 & 0.93 & - & - & - & - & - & - \\
\hline 4 & Asystasia gangetica & 06 & 0.93 & - & - & - & - & - & - \\
\hline 5 & Borreria ocymoides & 84 & 13.1 & 70 & 24.5 & - & - & - & - \\
\hline 6 & Borreria verticilata & 166 & 25.9 & 34 & 11.9 & - & - & - & - \\
\hline 7 & Cercurinegiasp & 06 & 0.93 & - & - & - & - & - & - \\
\hline 8 & Chromolaena odorata & 176 & 27.5 & 34 & 11.9 & 92 & 13 & 06 & 3.30 \\
\hline 9 & Chromolaena veronica & 06 & 0.93 & - & - & - & - & - & - \\
\hline 10 & Cissampelos owariensis & 06 & 0.93 & 72 & 25.2 & - & - & - & - \\
\hline 11 & Cormelina sp & 08 & 1.25 & - & - & - & - & - & - \\
\hline 12 & Croton lobatus & 06 & 0.93 & - & - & - & - & - & - \\
\hline 13 & Cyperus dactylon & - & - & - & - & 30 & 4.24 & - & - \\
\hline 14 & Dissotis idanrensis & - & - & - & - & 190 & 26.8 & 34 & 18.7 \\
\hline 15 & Dissotis rotundifolia & 32 & 5.00 & - & - & - & - & - & - \\
\hline 16 & Elaies guineensis & - & - & - & - & 166 & 23.4 & - & - \\
\hline 17 & Eleusine indica & 22 & 3.44 & - & - & - & - & - & - \\
\hline 18 & Fleurya aestuans & 24 & 3.75 & 16 & 5.59 & - & - & - & - \\
\hline 19 & Gouania longipetala & 06 & 0.93 & 12 & 4.20 & - & - & - & - \\
\hline 20 & Harungana madagascariensis & 06 & 0.93 & - & - & - & - & - & - \\
\hline 21 & Mallotus oppositifolius & - & - & - & - & 38 & 5.37 & 06 & 3.30 \\
\hline 22 & Mariscus alternifolius & - & - & - & - & 06 & 0.85 & - & - \\
\hline 23 & Oldenlandia corymbosa & - & - & - & - & 174 & 24.6 & 136 & 74.7 \\
\hline 24 & Oplismenus burmanni & 08 & 1.25 & - & - & - & - & - & - \\
\hline 25 & Peperomia pellucida & 06 & 0.93 & - & - & 06 & 0.85 & - & - \\
\hline 26 & Phyllanthus niruri & 08 & 1.25 & 06 & 2.10 & - & - & - & - \\
\hline 27 & Poulzolzia guineensis & 06 & 0.93 & - & - & - & - & - & - \\
\hline 28 & Schrankia leptocarpa & 08 & 1.25 & 06 & - & - & - & - & - \\
\hline 28 & Solenostemon rotundifolius & 06 & 0.93 & - & - & - & - & - & - \\
\hline 30 & Spilanthessp. & 06 & 0.93 & - & - & - & - & - & - \\
\hline 31 & Synedrella nodiflora & - & - & - & - & 06 & 0.85 & - & - \\
\hline 32 & Talinum triangulare & - & - & - & - & 06 & & - & - \\
\hline 33 & Terminalia ivorensis & 06 & 0.93 & - & - & - & - & - & - \\
\hline 34 & Trema orientalis & 06 & 0.93 & 06 & 2.10 & - & - & - & - \\
\hline \multirow[t]{2}{*}{35} & Vigna gracilis & 06 & 0.93 & 06 & 2.10 & - & - & - & - \\
\hline & Total & 640 & $100 \%$ & 286 & $100 \%$ & 708 & $100 \%$ & 182 & $100 \%$ \\
\hline
\end{tabular}

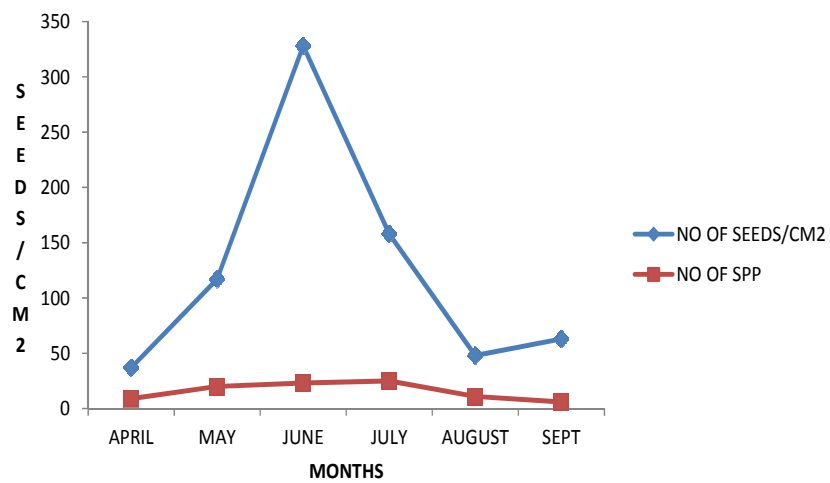

Fig. 3. Monthly emergence of seedlings and species at both depths from the dry season in riparian forest

\section{Seed bank and seasonal dynamics}

Total seed density ranged from 720 seeds $/ \mathrm{m}^{2}$ to 1242 seeds $/ \mathrm{m}^{2}$ in the dry season (fig. 4) and 354 seeds $/ \mathrm{m}^{2}$ to 924 seeds $/ \mathrm{m}^{2}$ in the rainy season in upland vegetation (fig. 6). The seed density was higher in the dry season than in the rainy season. Total seed density ranged from 468 to 1344 seeds $/ \mathrm{m}^{2}$ in the dry season (Fig.5) and 564 to 1338 seeds $/ \mathrm{m}^{2}$ in the rainy season in riparian forest (Fig.3). The seed density was higher in the dry season than in the rainy season.

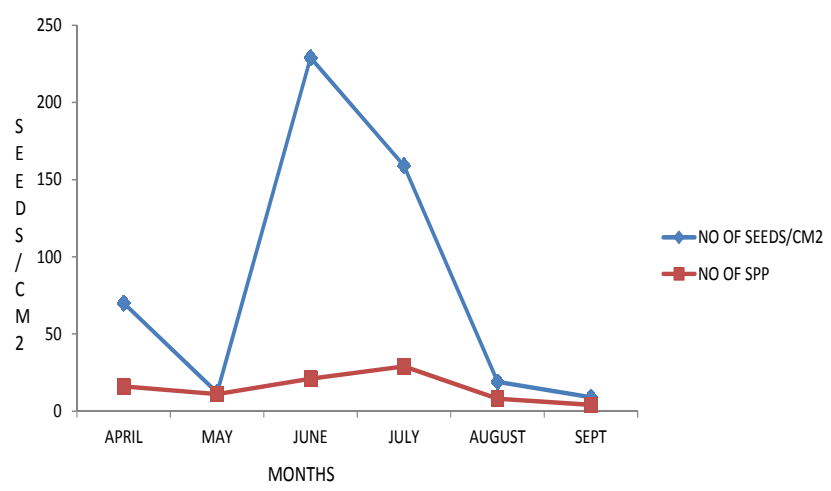

Fig. 4. Monthly emergence of seedlings and species at both depths from the dry season in upland vegetation

\section{Standing vegetation and seedbank}

Fifty one species emerged from the seed bank of riparian forest consisting of four woody species namely Alchornea cordifolia, Trema orientalis, Elaeis guineensis, Mallotus oppositifolia. Nevertheless, only one of the woody species that emerged from the seed bank (Alchornea cordifolia) was observed among the established woody vegetation while other woody species were absent in the standing vegetation. 
122

Table 4. Mean density $\left(\right.$ seeds $\left./ \mathrm{m}^{2}\right)$ and percentage contribution of each species in the seed bank of upland vegetation in both dry and rainy season at $0-15 \mathrm{~cm}$ and $15-30 \mathrm{~cm}$ depth

\begin{tabular}{|c|c|c|c|c|c|c|c|c|c|}
\hline \multirow[b]{2}{*}{$\mathrm{S} / \mathrm{N}$} & \multirow[b]{2}{*}{ Species } & \multicolumn{3}{|c|}{ Dry season $\left(\right.$ seeds $\left./ \mathrm{m}^{2}\right)$} & \multicolumn{5}{|c|}{ Rainy season $\left(\mathrm{seed} / \mathrm{m}^{2}\right)$} \\
\hline & & $0-15 \mathrm{~cm}$ & $\%$ seed bank & $15-30 \mathrm{~cm}$ & $\begin{array}{c}\% \text { seed } \\
\text { bank }\end{array}$ & $0-15 \mathrm{~cm}$ & $\%$ seed bank & $15-30 \mathrm{~cm}$ & $\%$ seed bank \\
\hline 1 & Ageratum conyzoides & 28 & 3.85 & 12 & 3.87 & - & - & 06 & 1.87 \\
\hline 2 & Andropogon sp & 06 & 0.82 & - & - & - & - & - & - \\
\hline 3 & Aneilla sp. & 22 & 3.02 & 08 & 1.94 & - & - & - & - \\
\hline 4 & Aristolochia ringens & 10 & 1.37 & - & - & 06 & 1.16 & - & - \\
\hline 5 & Aspillia africana & - & - & - & - & 06 & 1.16 & - & - \\
\hline 6 & Asystasia gangetica & 06 & 0.82 & 06 & 1.94 & - & - & - & - \\
\hline 7 & Blumea lacera & - & - & - & - & 06 & 1.16 & - & - \\
\hline 8 & Borreria ocymoides & 96 & 13.2 & 92 & 29.7 & - & - & - & - \\
\hline 9 & Borreria verticilata & 60 & 8.24 & 18 & 5.81 & - & - & - & - \\
\hline 10 & Chromolaena odorata & 216 & 29.7 & 72 & 23.2 & 226 & 43.8 & 20 & 28.6 \\
\hline 11 & Croton lobatus & 10 & 1.37 & 06 & 1.94 & - & - & - & - \\
\hline 12 & Desmodium sp & 32 & 4.40 & 06 & 1.94 & 06 & 1.16 & - & - \\
\hline 13 & Dissotis idanrensis & - & - & - & - & 26 & 5.04 & - & - \\
\hline 14 & Dissotis rotundifolius & 06 & 0.82 & - & - & - & - & - & - \\
\hline 15 & Elaeis guineensis & - & - & - & - & 122 & 23.6 & - & - \\
\hline 16 & Eleusine indica & 62 & 8.52 & 34 & 11.0 & - & - & - & - \\
\hline 17 & Euphorbia germinus & 06 & 0.82 & - & - & - & - & - & - \\
\hline 18 & Euphorbia heterophyla & 06 & 0.82 & - & - & - & - & - & - \\
\hline 19 & Euphorbia migrant & - & - & - & - & 06 & 1.16 & - & - \\
\hline 20 & Faroa pasilla & - & - & - & - & 16 & 3.10 & - & - \\
\hline 21 & Fleurya aestuans & 50 & 6.87 & 20 & 6.45 & - & - & - & - \\
\hline 22 & Fluggea virosa & - & - & - & - & 06 & 1.16 & 18 & 25.7 \\
\hline 23 & Grewia orientalis & 06 & 0.82 & 06 & 1.94 & - & - & - & - \\
\hline 24 & Ipomoea involucrata & 06 & 0.82 & - & - & - & - & - & - \\
\hline 25 & Mariscus alternifolius & - & - & - & - & 16 & 3.10 & - & - \\
\hline 26 & Mimosa pudica & - & - & - & - & 14 & 2.71 & - & - \\
\hline 27 & Oldenlandia corymbosa & - & - & - & - & 16 & 3.10 & 18 & 25.7 \\
\hline 28 & Peperomia pellucida & 06 & 0.82 & - & - & 06 & 1.16 & - & - \\
\hline 29 & Phaelopsis barteri & - & - & - & - & 06 & 1.16 & 06 & 8.75 \\
\hline 30 & Phylanthus niruri & 14 & 1.92 & 06 & 1.94 & - & - & - & - \\
\hline 31 & Physalis micratal & - & - & - & - & 06 & 1.16 & - & - \\
\hline 32 & Schrankia leptocarpa & 06 & 0.82 & - & - & - & - & - & - \\
\hline 33 & Solenostemon rotundifolius & 06 & 0.82 & - & - & - & - & - & - \\
\hline 34 & Spamicosa aximoides & - & - & - & - & 06 & 1.16 & - & - \\
\hline 35 & Spilanthes sp. & 10 & 1.37 & 06 & 1.94 & - & - & - & - \\
\hline 36 & Spigelia anthelmia & 28 & 3.85 & 06 & 1.94 & - & - & - & - \\
\hline 38 & Synedrella nodiflora & - & - & - & - & 06 & 1.16 & - & - \\
\hline 39 & Talinum triangulare & 06 & 0.82 & 06 & 1.94 & 06 & 1.16 & - & - \\
\hline 40 & Trema orientalis & 12 & 1.64 & - & - & - & - & - & - \\
\hline 41 & Veronica abyssinica & 06 & 0.82 & - & - & - & - & - & - \\
\hline \multirow[t]{2}{*}{42} & Vigna gracilis & 06 & 0.82 & 06 & 1.94 & 08 & 1.55 & - & - \\
\hline & Total & 728 & $100 \%$ & 310 & $100 \%$ & 516 & $100 \%$ & 70 & $100 \%$ \\
\hline
\end{tabular}

Table 5. Summary of mean density of seeds $/ \mathrm{m}^{2}$ at different depths in both seasons in the two vegetation types

\begin{tabular}{llll}
\hline Season & Depth $(\mathrm{cm})$ & Riparian & Upland \\
\hline \multirow{2}{*}{ Rainy } & $0-15$ & 708 & 516 \\
& $15-30$ & 182 & 70 \\
\multirow{2}{*}{ Dry } & $0-15$ & 640 & 728 \\
& $15-30$ & 286 & 310 \\
\hline
\end{tabular}

In the upland vegetation, forty one species emerged from the soil seed bank in both seasons at different depths, consisting of only four woody species namely Trema orientalis, Elaeis guineensis, Harungana madagascariensis and Grewia orientalis. Trema orientalis and Harungana madagascariensis were only the two woody species that had representative in the standing vegetation (Fig. 7).

\section{Discussion}

Species composition of the standing vegetation

The density of the woody species varied considerably in the two vegetation types under consideration. There were more

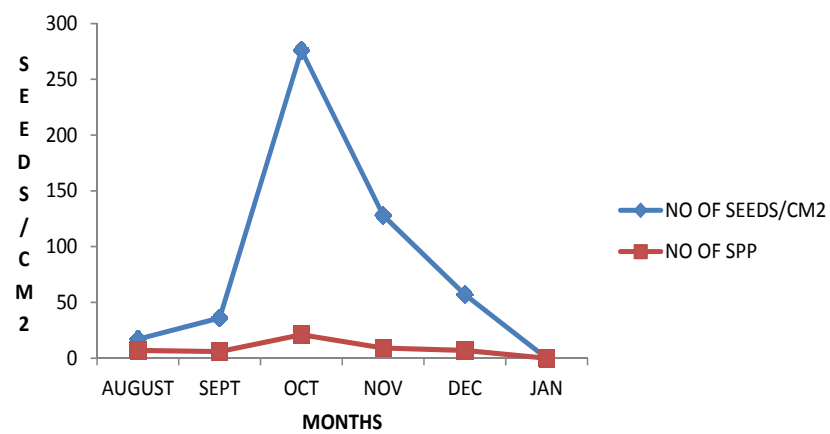

Fig. 5. Monthly emergence of seedlings and species at both depths from the rainy season in riparian forest

woody species in the upland vegetation than the riparian forest. This could be as a result of multiple natural disturbance regimes such as flooding, debris torrents, channels migration and landslides as well as trees-falls that occur in riparian areas compared to upland vegetation where tree-falls take is the only disturbance (Gregory et al., 1991, Naiman et al., 1993). 


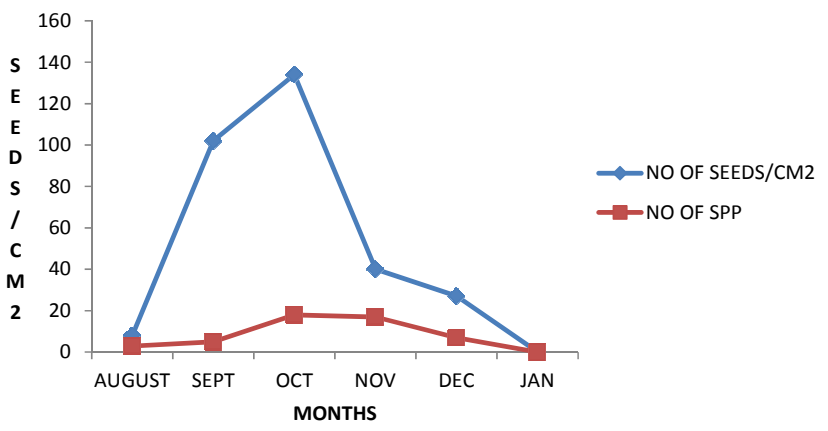

Fig. 6. Monthly emergence of seedlings and species at both depths from the rainy season in Upland vegetation

Numerous factors such as interspecific interactions, habitat modification, seedling bank, availability of resources, disturbance may influence the vegetation composition in these forests (Conell, 1989; Dalling et al; 2002). The current study came in contradiction to the report of Correll (1997) who reported that vegetation density was higher in riparian forest compared to adjacent upland vegetation.

\section{Seed bank density in the riparian forest and adjacent upland vegetation.}

The mean seed bank density of these study sites ranged from 70 to 728 seeds $/ \mathrm{m}^{2}$ and was lower than the values reported for some other forest of the world. For instance, Teketay and Gransterom (1995) recorded 12,300 seeds $/ \mathrm{m}^{2}$ in their study of an Afro-Montane forest in Ethiopia. The lower seed density obtained in this study can be ascribed to the modes of production of seeds and their dispersal (GromboneGuaratini, 2004). Herbaceous species recorded the highest number of seeds as compared to the other life forms at different depths and seasons in both the riparian forest and adjacent upland vegetation. The contribution of woody species was low in both the riparian forest and adjacent upland vegetation types; perhaps the herbaceous species could produce persistent seed banks. This is in agreement with Zheng et al. (2004) who observed that herbaceous species dominated the soil seed banks. Also Taye (2006) observed that the soil seed bank of Harena forest was dominated by herbaceous species. Oke $e t$ al. (2006) also observed that herbaceous species dominated the seed bank of a secondary low forest in Nigeria.

The presence of few woody species like Alchornea cordifolia, Trema orientalis, Elaeis guineensis, Mallotus oppositifolia, Harungana madagascariensis and Grewia orientalis in the soil seed bank of the riparian forest and the adjacent upland vegetation may be that majority of the forest canopy species of the forest do not have viable seeds in the soil seed bank or that the viable seeds of the canopy species do not meet their germination requirement under glasshouse conditions.

\section{Seasonal dynamics of soil seed bank}

The seed bank density was higher in rainy season (2700 seeds $\left./ \mathrm{m}^{2}\right)$ than in dry season $\left(2508\right.$ seeds $\left./ \mathrm{m}^{2}\right)$. This result was similar to that reported by Grombone-Guaratini and Rodrigues (2002), who found that the seed density during dry season was lower than in rainy season in a seasonal semi deciduous forest. Seed banks may exhibit higher density and diversity in areas of variable hydrologic conditions (La Peyre et

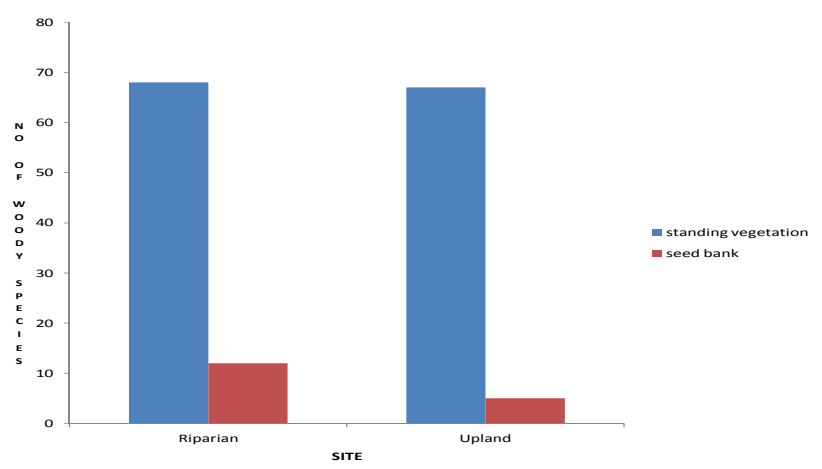

Fig. 7. Number of woody species in both standing vegetation and seed bank of the two vegetation types

al., 2005) and substrate heterogeneity, such as those found in the riparian corridor (Schneider and Sharitz 1986). This might be responsible for the high density of soil seed bank of the riparian forest assessed in this study in rainy season soil collection. In contrary, the seed densities of upland vegetation in the dry season $\left(2922\right.$ seeds $\left./ \mathrm{m}^{2}\right)$ were higher than that of rainy season $\left(1644\right.$ seeds $\left./ \mathrm{m}^{2}\right)$. This is in agreement with Grombone-Guaratini et al. (2004) who reported that seed density in dry season was higher than that of rainy season in the seed bank of a gallery forest in Southeastern Brazil. The increase in seedling density during dry season in upland vegetation may be that most seeds in the soil seed bank met favourable environmental conditions to enhance their germination at this period, because favourable weather is a critical factor that determines the fate of seeds stored in the seed bank, whether to germinate or remain dormant. Various researchers have reported similar results on the seasonal dynamics of soil seed bank: Oke et al. (2007); Coffin and Lauenroth (1989); Butler and Chadzon, 1998).

\section{Soil seed bank and soil depths}

The seed density decreased with increase in the depth in this study. This implies that the seed density relates inversely with the soil depth.. A depth related decrease in soil seed bank has been documented (Roberts, 1972; Russiet et al., 1992). The results from this study showed that the rate of seedling emergence was higher at $0-15 \mathrm{~cm}$ depth than $15-30 \mathrm{~cm}$. This observation is in agreement with Cox and Martin (1984); Malik et al (2006); Bossuyt et al. (2002) This pattern can be attributed to historical changes in above-ground vegetation and seed bank regime (McGraw, 1987), seed mass and shape (Bekker et al., 1998), as well as the vertical transport of seeds by earthworms, burrowing rodents and ants (Willems and Huijsmans, 1994) and probably differences in the slope of the landscape and local edaphic conditions of where the seeds land during dispersal.

\section{Conclusions}

Herbaceous species recorded the highest number of seedlings as compared to the other habit and few woody species emerged from the seed bank of the two study sites. The dissimilarity between seed bank and above-ground vegetation of riparian forest and the adjacent upland vegetation of the present study area has revealed that soil seed bank is insignificant in the restoration of degraded riparian forest and upland vegetation. 
124

\section{References}

Augusto Uasuf, Tigabu M, Odén PC (2009). soil seed banks and regeneration of neotropical dry deciduous and gallery forests in Nicaragua. Bois et Forêts Des Tropiques N 299 (1).

Bakker JP, Berende F (1999). Constraints in the restoration of ecological diversity in grassland and healthland communities. Ecology of Evolution 14:63-68.

Bekker RM, Bakker JP, Grandin U, Kalamees R, Milberg P, Poschlod P. (1998). Seed size, shape and vertical distribution in the soil: Indicators of seed longevity. Functional Ecology 12:834-842.

Bossuyt B, Heyn M, Hermy M (2002). Seed bank and vegetation composition of forest stands of varying age in Central Belgium: consequences for regeneration of ancient forest vegetation. Plant Ecology 162:33-48.

Butler BJ, Chazdon RL (1998).Species richness, spatial variation and abundance of the soil seed bank of a secondary tropical rain forest. Biotropica 30(2):214-222.

Coffin DP, Lauenroth WK (1989). Spatial and temporal variation in the seed bank of a semiarid grassland. American Journal of Botany 76: 53-58.

Connell, JH (1989). Some processes affecting the species composition in forest gaps. Ecology 70:560-562.

Correll DL (1997). Buffer zones and water quality protection: General principles. In: Hancock NE et al. (Eds.). Buffer zones: Their processes and potential in water protection. Quest Environmental. Hertfordshire, England.

Cox JR, Martin MH (1984). Effects of planting depths and soil textures on the emergence of four love grasses. Journal Range Management 37:204-205.

Dalling JS, Hubbell SP (2002). Seed size, growth rate and gap microsite conditions as determinants of recruitment success for pioneer species. Journal of Ecology 90:557-568.

Gregory SV, Swanso FJ, McKee WA, Cummins KW (1991). An ecosystem perspective of riparian zones. BioScience 41:540-551.

Grombone-Guaratini MT, Rodrigues RR (2002). Seed bank and seed rain in a seasonal semi deciduous forest in south-eastern Brail. Journal of Tropical Ecology 18:759-774.

Grombone-Guaratine MT, Leitão-Filho HF, Kageyama PY (2004). The seed bank of a gallery forest in south eastern Brazil. Brazilian Archives of Biology and Technology 47:793-797.

Holzel N, Otte A (2004). Assessing soil seed bank persistence in floodmeadows: The search for reliable traits. Journal Vegetation of Science 15:93-100.

Hutchinson J, Dalziel JM (1954). Flora of West Tropical Africa. White Fnars Press, London. Revised by Crown Agents, London.

Ilhardt BI, Verry ES ,Palik BJ (2000). Defining riparian areas. In: Riparian management of the Continental Eastern United States. Lewis Publishers, New York.432pp.

Keay RWJ (1959). An outline of Nigerian vegetation (3 $3^{\text {rd }}$ ed.). Government Printer, Lagos, Nigeria.

La Peyre MKG, Bush Tom CS, Winslow C, Caldwell A, Nyman JA (2005). Comparison of seed bank size and composition in fringing, restored and impounded marsh in southwest Louisiana. Southeastern Naturalist 4:273-86.
Malik SA, Khan S, Dasti AA, Akram M, Saima S (2006). Effect of planting depths on emergence and seedling morphology of Zea mays L. planting depths on seed germination and seedling growth of some crop plants. M.Sc.Thesis, Botany Department, Bahauddin Zakariya University, Mult.

Mayor J, Pyott WT (1966). Buried viable seeds in two California bunch grass sites and their bearing on the definition of a flora. Vegetation 13:253-282.

McGraw JB (1987). Seed-bank properties of an Appalachian sphagnum bog and a model of the depth distribution of viable seeds. Canadian Journal of Botany 65:2028-2035.

Naiman RJ, Decamps H (1990). Aquatic terrestrial ecotones: Summary and recommendations. In: Naiman RJ, Decamps H (eds). Ecology and management of aquatic-terrestrial ecotones. UNESCO, Paris, and Parthenon Publishing Group, Carnforth, UK.

Naiman RJ, Robert J, Decamps H, Henri, Pollock, Michael (1993). The role of riparian corridors in maintaining regional biodiversity. Ecological Applications 3(2):209-212.

Naiman RJ, Camps H (1997): The ecology of interfaces: riparian zones. Annual Review of Ecology and Systematics 28:621-658.

Oke SO, Isichei AO (1997). Floristic composition and structure of the fallow vegetation in Ile- Ife area, southwestern Nigeria. Nigerian Journal of Botany 10:37-50.

Oke SO, Oladipo OT, Isichei AO (2006). Seedbank dynamics and regeneration in a secondary lowland rainforest in Nigeria. International Journal of Botany 2(4):363-371.

Oke SO, Ayanwale TO, Isola. OA (2007). Soil seed bank in four contrasting plantations in Ile-Ife area of southwestern Nigeria. Research Journal of Botany 2:13-22.

Onochie CFA (1979).The Nigerian rain forest: an overview. In: Okali DUU. (Eed). The Nigerian rainforest ecosystem. National MAB Committee, Ibadan, Nigeria.

Roberts HA, Feast PM (1972). Fate of seeds of some annual weeds in different depths of cultivated and undisturbed soil. Weed Research 12:316-324.

Russiet L, Cocks PS, Roberts EH (1992). Seed bank dynamics in a Mediterranean grassland. Journal of Applied Ecology 29:763-771.

Schneider RL, Sharitz RR (1986). Seed bank dynamics in south eastern riverine swamp. American Journal of Botany 73:1022-1030.

Sorensen T (1948). A method of stablishing groups of equal amplitude in plant sociology based on similar species content and its application to analyses of vegetation on Danish commons. Biologiske Skrifte 5:1-34.

Taye J (2006). Canopy gap regeneration and dynamics in the afro montane forest of Bale Mountains. Unpublished Thesis, School of Graduate studies, Addis Ababa University.

Teketay D, Gransterom A (1995). Soil seed Banks in dry Afro Montane Forest of Ethiopia. Journal of Vegetation Science 6:777786.

Willems JH, Huijsmans KGA (1994). Vertical seed dispersal by earthworms: a quantitative approach. Ecography 17:124-130.

Zheng H, OuYang ZY, Wang XK, Peng TB (2004). Studies on the characteristics of soil seed banks under different forest restoration types in hilly red soil region, Southern China. Journal of Natural Resources 19:361-368. 